\title{
Tribunal Constitucional Internacional já!
}

\author{
Hélcio de Abreu Dallari Júnior ${ }^{1}$
}

Resumo: O mundo atual carece de uma estrutura global que traga maior segurança constitucional a todos os povos. A criação de um Tribunal Constitucional Internacional deverá trazer melhores respostas às aflições que violam a dignidade humana. Que tal Corte seja estabelecida!

Palavras Chave: ideal constitucional, dignidade humana, justiça, eficiência.

Abstract: The world, actually, lacks of a global structure which brings a wider constitutional security for everyone. The creation of an International Constitutional Court shall bring better answers to the afflictions that viotale the human dignity. This Court must be established!

Keywords: constitutional ideal, human dignity, justice, efficiency.

\section{Introdução}

Desde a primeira vez que me deparei com a ideia de criação de um Tribunal Constitucional Internacional, veio-me à lembrança o discurso proferido por Benjamim Franklin durante a sessão que aprovou a Constituição dos Estados Unidos da América, especialmente quando ele convoca os constituintes a aprovarem o texto, dizendo:

Tenho que confessar que eu não estou inteiramente de acordo com esta Constituição no momento; e, senhores, não tenho certeza se eu virei a aprovar um dia.

Por ter vivido muitos anos, tenho passado por muitas instâncias onde, em razão de melhores informações ou considerações mais amplas, fui obrigado a mudar de ideia até em assuntos mais importantes que pensei serem certos, mas que depois encarei de modo diferente. (...)

\footnotetext{
1 Tutor para Gestão Social do Banco Interamericano de Desenvolvimento (BID) and Instituto Interamericano para o Desenvolvimento Econômico e Social (INDES) - (Washington, D. C. - U.S.A.). MSc em Direito do Estado - Faculdade de Direito - Universidade de São Paulo (USP/SP - São Paulo BRAZIL). BSc em Ciências Jurídicas - Faculdade de Direito - Pontifícia Universidade Católica de São Paulo (PUC/SP - São Paulo - BRAZIL).
} 
A maioria dos homens e também a maioria das seitas religiosas pensam estar de posse de toda verdade, e aqueles que não concordam, consequentemente, estão errados. (...)

Com estes sentimentos, senhores, tenho que concordar com esta Constituição com todas as suas falhas - se é que se podem chamar assim - porque acho que um governo geral é necessário para nós, e não existe forma de governo, quando bem administrado, que não seja uma bênção para o seu povo, e também acredito que este aqui venha a ser bem administrado por alguns anos, e só resultará em despotismo, como outros o fizeram antes, quando o povo se tornar tão corrupto que se faça necessário um governo despótico, incapaz de formular qualquer outro.

Eu duvido também que outra convenção possa vir a formular uma Constituição melhor porque, quando você junta um grande número de homens, para ter a vantagem de sua sabedoria em conjunto, inevitavelmente virão também os seus preconceitos, paixões, seus erros de opinião, interesses locais, e seus pontos de vista egoístas. (...)

Então, dou meu consentimento para esta Constituição porque não espero por nenhuma outra melhor, e porque não tenho a certeza de que não é a melhor. Eu sacrifico as opiniões sobre seus erros, em nome do bem público. (...)

Em resumo, senhores, não posso deixar de pedir que todo membro desta convenção que ainda tiver alguma objeção, em relação a esta Constituição, tente junto comigo, nesta ocasião, duvidar um pouco de sua própria infalibilidade e, para manifestar a nossa unanimidade, coloque seu nome neste instrumento.

Assim, apesar da falibilidade humana, tenho a convicção que a união de virtudes de sábios constitucionalistas em um Tribunal Constitucional Internacional trará a maior retidão de consciência moral sobre as questões da dignidade humana, frente aos limites do bem comum.

Tais virtudes deverão estar fincadas na firmeza e durabilidade da inteligência e qualidades positivas de seus membros, para o alcance constante da plena razão humana. Deve-se buscar uma repetida atuação desta Corte, consoante os princípios da prudência, da justiça, da tempestividade e da eficiência.

Com o uso da prudência, deve-se compreender amplamente as circunstâncias (objeto, origem e motivações), conforme o que é oportuno e conveniente para o atingimento do bem comum. Por sua vez, o princípio da justiça deve trazer a pureza da consciência humana em garantir o que é devido, observada a temperança. A tempestividade visa o que é providencial, cabível em tempo hábil de efeitos. Por fim, a eficiência tem o encargo de trazer os melhores resultados com os meios disponíveis para tanto.

Falta-nos autoridade constitucional globalizada com legitimidade, empregando mecanismos lícitos e morais em respeito ao Estado de Direito, para maior 
segurança do bem de todos. Suas competências envolveriam o respeito e o desenvolvimento da promoção dos direitos humanos, individualmente e coletivamente considerados, extremamente necessários para a existência da paz e da segurança social.

É fato que o mundo atual é um mundo de incertezas. Existem muitos direitos e deveres previstos em Constituições pelo mundo que nem sempre se materializam. E, quando isso acontece, sobram incertezas, frustrações e situações de degradação humana.

Um Tribunal Constitucional Internacional certamente abrangerá diversas visões e análises constitucionais fundamentadas em evidências científicas de excelência. A Corte ora debatida surge como uma luz no fim do túnel, como um juízo constitucional da razão em benefício dos indivíduos, das famílias, das sociedades e dos Estados.

Será crucial que os documentos de origem do referido Tribunal estabeleçam de forma clara princípios, fundamentos e objetivos primordiais. Seus membros deverão ter amplo conhecimento interdisciplinar sobre as questões relacionadas ao campo de análise envolvido. Tudo que envolver a criação do mesmo deverá ganhar o máximo conhecimento e reconhecimento mundial possível por meio de uma vasta rede de divulgação e de uma linguagem moderna compreensível pelos povos.

Um outro detalhe crucial: invariavelmente, os membros de um Tribunal Constitucional Internacional deverão estar atentos à realidade das situações de mutabilidade da vida humana, de acordo com cada localidade.

Que tal Corte tenha apego persistente à visão justa, fraterna e solidária da doutrina constitucional, respondendo aos apelos de um mundo violento, carente de soluções efetivas, inclusive pontificando orientações para o fortacelimento constitucional global. Para tanto, temas centrais deverão ser definidos, combatendo regimes de exceção atentatórios à dignidade humana. Em sendo assim, naturalmente surgirão mais e mais simpatizantes, seguidores e partidários.

Pensar um Tribunal Constitucional Internacional é pensar além de sua criação, é pensar também as estratégias de seu desenvolvimento firme de consciência moral e bem-aventurança.

\section{Conclusões}

Que este momento seja de reflexão constitucional global!

Que este momento seja de esforço comum de sábios constitucionalistas defençores da doutrina convertente da dignidade humana! renovação!

Que este momento seja de promoção do ideal constitucional e de sua saudável

Que este momento seja de vivência constitucional ativa e participativa! 


\section{Referências}

FRANKLIN, Benjamin. Discurso feito em 17 de setembro de 1787, na sessão da Convenção Constitucional, que aprovou por unanimidade a Constituição dos Estados Unidos da América. 100 Discursos Históricos, p. 176-178, 2002.

Recebido para publicação em 05-09-15; aceito em 02-10-15 